\title{
Sushi Domain-Containing Protein 1
}

National Cancer Institute

\section{Source}

National Cancer Institute. Sushi Domain-Containing Protein 1. NCI Thesaurus. Code C114403.

Sushi domain-containing protein 1 (747 aa, $\sim 83 \mathrm{kDa}$ ) is encoded by the human SUSD1 gene. This protein is involved in calcium binding. 